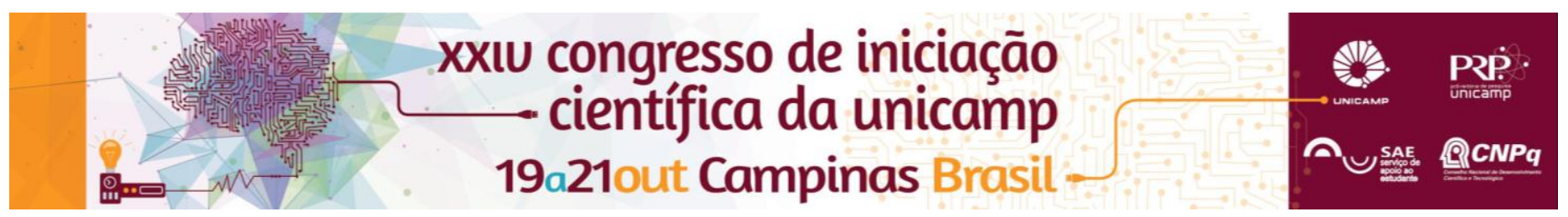

\title{
Estudo das técnicas empregadas para escavação e construção de túneis em solo e rocha
}

\section{Erik S. Paula*, Paulo J. R. Albuquerque.}

\section{Resumo}

Túneis vêm sendo construídos a milhares de anos com objetivo de superar obstáculos naturais, como montanhas, cursos d'água fluviais e marinhas, assim como artificiais, decorrentes da demasiada urbanização dos grandes centros urbanos. Muitas são suas finalidades, como para passagem de trem, de automóveis e pedestres, para tubulações de água e esgoto, para passagem de rede elétrica e de comunicação, dentro outros. Com o passar do tempo e com o avanço da tecnologia as técnicas utilizadas nas escavações dos túneis vêm sendo renovadas e melhoradas. Atualmente as técnicas existentes vêm sendo levadas aos seus limites para que atinjam altas eficiências, sem riscos de acidentes e que superem as barreiras impostas. Este projeto visa fazer um estudo sobre o estado da arte das atuais técnicas de escavações de tuneis, como: Tunnel Boring Machine, New Austrian Tunneling Method e The Cut-and-Cover Method, buscando abordar seus históricos, motivações da criação e os seus usos em grandes obras, os pontos geotécnicos e técnicos das escavações e sustentações de tuneis, e os pontos positivos e negativos quanto a outras vertentes.

\section{Palavras-chave}

Túnel, Métodos, Histórico.

\section{Introdução}

A primeira técnica de escavação utilizada em construções de túneis era a de execução à mão com o auxílio de ferramentas manuais. Esta técnica, préhistórica, deu origem a muitas outras técnicas, conforme era exigido pelas mudanças das necessidades das civilizações e pelo avanço tecnológico.

Durante o período de existência da babilônia foi desenvolvido outro método, o Cut-and-Cover, o qual ainda é bastante utilizado hoje em dia. Outros métodos e técnicas de perfurações também foram surgindo. Surgiram às pólvoras, os explosivos, as dinamites, e a técnica de ar comprimido, e todos estes foram aplicados nas escavações. Na revolução industrial surgiram os maquinários e as metodologias se alavancaram.

Com o grande avanço em tecnologia que a revolução industrial proporcionou as técnicas de construção dos túneis se dividiram em duas grandes correntes, a corrente mecanizada e a de mineração, ou manual. A primeira conta com o TBM como referência, enquanto que a segunda conta com o NATM.

Posto isso, visa-se realizar um estudo sobre o estado da arte das atuais técnicas de escavações de túneis e apontar seus pontos positivos e negativos.

\section{Resultados e Discussão}

O NATM apresenta como ponto forte e tem como sua marca registrada, a versatilidade em adaptação. Isto porque em seu método a frente de escavação não é obstruída e é possível acessa lá com facilidade para verificação do maciço e da ancoragem que esta sendo aplicada, e, conforme necessário, pode-se modificar sem grandes dificuldades a geometria da seção transversal, o processo de escavação, e também realizar trocas de ferramentas de ancoragens dentre outras.

No TBM o ponto forte e positivo da metodologia é que a tuneladora, equipamento essencial à aplicação do método, realiza todo o processo de escavação, sustentação e ancoragem do maciço, em caráter definitivo. Contudo este é um método extremamente caro, e sua aplicação somente é adequada para túneis com extensões superiores a três quilometres.

O método Cut-and-Cover pode ser dividido em dois sub métodos, o primeiro deles apresenta como pontos fortes a sustentabilidade, o fornecimentos de uma seção segura de acesso ao subsolo, durante a construção do túnel, e uma completa estabilidade geotécnica do local, contudo requer grande escoramento do maciço. O segundo apresenta menor impacto superficial, requer menos escoramento e tem alta aplicabilidade em situações adversas, e também é um método relativamente barato, entretanto proporciona dificuldades para mobilidade urbana local.

\section{Conclusões}

Atualmente existem muitas técnicas diferentes de escavações de túneis, e cada uma delas apresentam certas particularidades. Na escolha do método para utilização num projeto, o bom conhecimento geológico local e a boa compreensão do funcionamento dos métodos é o que faz a diferença na escolha apropriada.

\footnotetext{
${ }^{1}$ MOREIRA, C. Túneis, uma herança ancestral rumo ao futuro. A obra nasce: revista de Arquitectura da Universidade Fernando Pessoa. Porto: Fundação de Ensino e cultura Fernando Pessoa, p. 92-115, jan.2006.
} 